\title{
Writings of the Subsoil in the Contemporary Congolese Novel
}

\author{
Xavier Garnier | ORCID: 0000-0003-3641-673X \\ Université de la Sorbonne Nouvelle, Paris, France \\ Xavier.garnier@wanadoo.fr
}

\begin{abstract}
The expression "geological scandal," used at the end of the nineteenth century by the Belgian geologist Jules Cornet to describe the mineral wealth of the eastern Congo, has become even more relevant today if we think of the misfortunes that affect the region. Global predation in this part of central Africa is naturally at the heart of the literary preoccupations of many Congolese writers, who invent narrative forms that are able to account for what is being played out beneath the earth's surface, in the bowels of the earth. In this paper, I wish to highlight the literature of the mine that begins in the colonial era of the Congolese novel and develops considerably in contemporary times. Through the reading of a few major Congolese novels, this article analyzes how the Congo's subsoil is the vector of globalization.
\end{abstract}

\section{Keywords}

Congolese literature - ecocriticism - postcolonial studies - mine writing - extractivism

\section{Introduction}

Due to the wealth of the subsoil and the development of major mining projects, the presence of diggers is increasingly frequent in the contemporary Congolese novel. ${ }^{1}$ If the wealth of Central Africa lies within its deepest layers, it is not surprising that people living in poverty and violence seek to get there. In an

1 From the colonial era, Congolese literature quickly recognized the subterranean as a crucial 
African context marked, since the beginning of the colonial era, by an imperial project based on extractivism, what is at stake underground, in the subterranean wealth of the continent, is crucial to the distribution and the organization of territories. The notion of "deeps" was coined by Martinican writer Édouard Glissant to convey the tangible experience of places in the world that cannot be reduced to their exotic representations: "Deeps (les profonds) are, if you will, the concreteness of depth (la profondeur), what is actually, and really, underneath the surface. It is quite simplistic, but I think that all the volcanoes in the Caribbean are interconnected underground, through sort of lava flows that are highways of their power and overflowing"2 (Glissant and Noudelmann 65; our translation). Through its focus on the tangibility of reality, the "literature of deeps" stands in contrast to the conception of depth inherited from the colonial imaginary, such as "l' Afrique profonde" or "the real bush." The deeps are, for Glissant, energies born from contact with what is concretely lurking underneath the visible; they refer to a concrete experience of matter. Beneath the earth's crust is buried a wealth that can be extracted. In place of a horizon line oriented from four cardinal points, a vertical axis goes from zenith to nadir and can be followed to penetrate into this different orientation of space.

\section{$2 \quad$ Writing the "Global Congo" through the Critical Zone}

The pygmy narrator of In Koli Jean Bofane's novel Congo Inc.: Bismarck's Testament (2014) seeks connections all over the world that are likely to make the ground of his country more valuable. The thickness of the soil, which is for him the condition of its habitability, is born of a superimposition of surfaces or layers. The novel opens with an extraordinary invocation of the forest as an intermingling of surfaces, which ends with the mention of its subterranean empires in layers under the ground: "At ground level and beneath it, in the kingdom of the porcupine and the armadillo, the ant and the centipede, invisible and sprawling empires continued to be built and deconstructed under the rule

space. The spirits of the river in Paul Lomami-Tchibamba's Ngando (1948) live under the surface of the water in nearly subterranean conditions.

2 'Les profonds c' est, si vous voulez, la concrétude de la profondeur, ce qu'il y a réellement, concrètement, en dessous de l'apparence. C' est assez enfantin, mais moi je pense que tous les volcans de la Caraïbe correspondent souterrainement entre eux, par des sortes de coulées de lave qui sont les autoroutes de leur puissance et de leur débordement." 
of avid and omnipotent rulers reigning peoples deprived of light"3 (12). The forest is a dense or "thick" space par excellence. Between the canopy and the layer of humus on which one walks, an atmospheric band spreads, which has its own characteristics: smells, resonances, and humidities. What some scientists have called the Critical Zone ${ }^{4}$ is this metamorphic zone, a relatively thin layer on which living beings depends (Latour 55). Bofane's forest, with its canopy, soil, and subsoil, has the structure of the Critical Zone.

Born in the dense forest, Isookanga, the main character of Congo Inc., is used to layers, and his stay in Kinshasa confirms that he relates to the world as a forest dweller. By consorting with shégés, street children considered to be wizards, Isookanga lives in the city in the manner of a hunter. The town is an area where movement is both a way to orient and to survive. Like the inhabitants of the forest, street children are masters of the art of playing with the different strata of the city. They are ubiquitous and furtive presences that remind us of the precariousness of our habitats:

There were some in the tunnels, on the sidewalks, in the recesses, on top of the dumps, perched on the low walls, at the foot of the steps leading into the administration buildings, at the Limete interchange, at the Yamaka forest. They swarmed, like rats in the sewers of New York, Paris or Mumbai, the spawn of different epidemics, plagues generated by the state, such as poverty, exclusion, poor governance, war. They vibrated in the city, invisible like germs on a long-standing gangrenous tissue. ${ }^{5}$

BOFANE 102

3 "Au niveau du sol et sous celui-ci, au royaume du porc-épic et du tatou, de la fourmi et de la scolopendre, des empires invisibles et tentaculaires continuaient de se bâtir et de se déconstruire sous la férule de souveraines avides et omnipotentes régnant sur des peuples privés de lumière." All translations, unless otherwise indicated, are mine. Marjolijn de Jager's English translation of Bofane's novel was published in 2018.

4 "The critical zone (cz), a term coined by the US National Research Council in 2001, encompasses the thin outer veneer of Earth's surface, extending from the top of the vegetation canopy down to the subsurface depths of fresh groundwater, the zone 'where rock meets life'" (White and Sharkley, Critical Zone Oxford Bibliography. Oxford Bibliographies (online). DOI: 10.1093/OBO/9780199363445-0055 (30 May, 2021)).

5 "Il y en avait dans les tunnels, sur les trottoirs, dans les recoins, sur les dépotoirs, juchés sur les murets, au pied des marches des administrations, à l'échangeur de Limete, à la forêt de Yamaka. Ils pullulaient, comme des rats dans les égouts de New-York, Paris ou de Mumbai, issus de différentes épidémies de pestes générées par l'État, telles que la pauvreté, l' exclusion, la mal-gouvernance, la guerre. Ils vibrionnaient dans la ville, invisibles comme des microbes sur un tissu gangrené de longue date." 
Shégés are one with the materiality of the city, and, at the same time, they are globalized symptoms. The space they occupy is borderless because there are epidemic outbreaks of gangrene that have corrupted the thickness of the tissue, above and below. Bruno Latour would say that street children force us to realize that our territories are fragile, and that if we want to continue living on earth it will be necessary to understand that they are caught in the Critical Zone:

If we want to defend our affiliations, we shall have to identify these migrations also, migrations without form or nation that we know as climate, erosion, pollution, resource depletion, habitat destruction. Even if you seal the frontiers against two-legged refugees, you cannot prevent these others from crossing over.

"But then is no one at home any longer?"

No as a matter of fact. Neither state sovereignty nor inviolable borders can take the place of politics any longer.

Shégés testify to a form of social disruption as globalized as climate disturbance. Taking them into consideration brings us out of the dialectic of local and global to think in terms of spatial dynamics. Shégés are deposits, a thin film covering the world and our territories. They make us understand that our countries are not limited by national borders, but by the contacts they maintain on a vertical axis, with the atmospheric and geological strata above and below.

In Sinzo Aanza's Généalogie d'une banalité ("Genealogy of a Banality") (2015), the entire city of Elisabethville is troglodyte due to the copper rush that consumes all of its residents, even as their homes are swept away by heavy rains and their neighborhoods kept afloat by humanitarian NGO s:

In the weeks that followed, people spent more time underground than in tarpaulin shelters. Many had preferred to work as a family. The mother dug, the father went up the surface and the children picked up what was likely to be malachite. Those who still had a house standing were digging in a corner of their small plots, whose irregularity and uncertain limits began to pose a problem. For as long as they had lived there, it had not mattered to them where their yards exactly ended, or even if the neighbor, having got up in the morning, had thrown his urine on across their property line; but now that it was a question of money, everyone wanted to make sure that the neighbor's hole did not overflow onto his property, 
because then he would have to pay a tax, a percentage on the ore of the imprudent one. ${ }^{6}$

${ }^{15}{ }^{8-59}$

The turbulence does not come from the horizon line but from what circulates along a vertical axis. Territories are disturbed by the deeps. With the map of minerals in the forest around his village, Isookanga dreams of underneath strata at the end of the novel: "The young man, meanwhile, had in mind only those vast dark green surfaces which, discreetly, contained auriferous tablecloths under layers of vegetation that seemed to be nothing"7 (Bofane 294). Following his globalist projects, Isookanga is very aware that once awakened, the lower strata of the forest can move to the surface of the earth and interfere in territorial organizations.

\section{3}

\section{Connecting the World through the Holes}

Once we have become aware that we live on top of layers, holes take on considerable importance, since it is through them that we can move from one stratum to another. The hole is an airlock or hatch. We fall in or out. It is a place of tilting between visibility and invisibility. The relationship between the hole and the gallery is an important poetic issue in Fiston Mwanza Mujila's novel Tram 83 (2015). In many ways, the café "Tram 83 " associated with the railway station plays the role of a hole. In the spatial organization of the novel, there is a continuity between the restaurant-bar, the railway station, the railroad track, and the mining galleries. The station is a hole that extends into the "gallery" of the railway station that plunges into the hinterland. The trains come out of the

6 "Les semaines qui suivirent, les gens passaient plus de temps sous la terre que dans les abris en bâches. Beaucoup avaient préféré travailler en famille. La mère creusait, le père remontait la terre en surface et les enfants ramassaient ce qui était susceptible d'être de la malachite. Ceux qui avaient encore une maison debout creusaient dans un coin de leurs petites parcelles dont l'irrégularité et les bornes arbitraires commencèrent à poser problème. Tant qu' ils ne faisaient qu'y vivre, ça leur importait peu de savoir jusqu' où allait leur terre, ou même de s'assurer que le voisin, en se levant le matin, n' avait pas jeté ses urines de l'autre côté de la ligne de démarcation; maintenant qu'il était question d'argent, tout le monde voulut s' assurer que le trou du voisin ne débordait pas sur sa propriété, ce qui impliquait qu' il devrait prélever un tribut, un pourcentage sur le minerai de l'imprudent."

7 "Le jeune homme quant à lui n' avait plus en tête que ces vastes surfaces vert foncé qui, discrètement, renfermaient des nappes aurifères sous des épaisseurs de végétation n' ayant l' air de rien." 
subsoil and dump out diggers who are haggard or dazed. The "restau-bar" is the nocturnal center of the city and country:

Tram 83 was one of the busiest whore restaurants and bars. Its fame extended beyond the borders of the City-Country. "See the Tram 83 and explode!" repeated the tourists who came from the four corners of the earth to expedite current affairs. During the day, they roamed like zombies in the mining concessions they owned in heaps and mounds, and, at night, they landed at Tram 83 in order to refresh their minds. Thus the place passed for a real theater in the absence of an actual circus. ${ }^{8}$

$14-15$

Filip De Boeck and Sammy Baloji devote a chapter of their book on Kinshasa to the "holes" that tear through the urban fabric and that generate areas of informal overactivity. They note that many bars and nightclubs are perceived as holes:

A couple of years ago, a Kinois businessman opened a dance bar next to the Forescom tower and called it Le Grand Libulu, "The Big Hole." The formula proved successful and the owner opened two more bars with the same name in more distant parts of the city. In the meantime, the name has also been adopted by other more informal small pubs and dancing bars throughout the city, inspiring a typical Kinois response to the subject of holes: "If we have to live in a hole, we might as well dance in it."

223

Tram 83 narrates this dance around the ruins of the infrastructure of the colonial era whose station, with its metal frame, is an emblem. The novel takes place in a "locomotive city," in which each character digs his own gallery and advances on its rails in relation to the effervescence of the common hole, Tram 83. This may be the way to understand the notion of locomotive literature in Mujila's novel, as the locomotive novel puts the characters on rails, like diggers in their gallery:

8 "Le Tram 83 était du nombre des restaurants et bars à traînées les plus achalandés. Sa renommée s' étendait au-delà des frontières de la Ville-Pays. Voir le Tram 83 et crever, rabâchaient les touristes qui débarquaient des quatre coins de la terre pour expédier les affaires courantes. La journée, ils erraient tels des zombies dans les concessions minières qu' ils possédaient à tour de bras et, la nuit, ils atterrissaient au Tram 83, histoire de se rafraîchir la mémoire. Ainsi l'endroit passait pour un vrai théâtre à défaut d' un grand cirque." 
Locomotive-literature or train-literature or tram-literature or railsliterature or railroad-literature or iron-lines-literature, my writing is in relationship with the railways that leave from the station, it boils down to a construction of unfinished metal, demolished by shells, rails and locomotives that bring to memory the railway line built by Stanley. ${ }^{9}$

One could also imagine a super-tanker literature, a cargo-plane literature, a pipeline literature that tells the way the story of extraction taking place on a global scale. From the point of view of a literature of the "Critical Zone," the questions of circulation are questions of galleries. Displacements engage bodies and assume logistics. Minors are diasporas. Ore is put in wagons and trucks. The galleries connect the places of extraction and places of consumption, which consist of so many holes that consequently make the world a huge burrow.

While members of NGO s come to bring equipment and medicines, the people who come out from underground look like zombies:

Old $\mathrm{Z}$ would scream from the top of the holes to warn his neighbors of the arrival of their generous and caring hosts. Dirty biologies then emerged from the earth, telling Prophet Zabulon that the neighborhood was definitely lost. For him, the neighbors anticipated the biblical atmosphere of the resurrection of the dead. Men and women in rags, almost naked, flip-flops and mud dripping, their faces shining despite the filth, where the Westerners of the NGOS saw a kind of collective depression - of pannévrose. ${ }^{10}$

AANZA 165

"Littérature-locomotive ou littérature-train ou littérature-tram ou littérature-rails ou littérature-chemin de fer ou littérature-lignes de fer, mon écriture accuse des parentés avec les chemins de fer qui partent de la gare qui se résume à une construction métallique inachevée, démolie par des obus, des rails et des locomotives qui ramènent à la mémoire la ligne de chemin de fer construite par Stanley."

10 "Vieux $\mathrm{Z}$ allait crier du haut des trous pour prévenir ses voisins de l' arrivée de leurs hôtes si généreux et si bienveillants. Des biologies sales surgissaient alors de la terre, faisant dire à prophète Zabulon que le quartier était définitivement perdu. Pour lui, les voisins anticipaient l' ambiance biblique de la résurrection des morts. Hommes et femmes en haillons, presque nus, flapis et dégoulinants de boue s' avançaient, le visage illuminé malgré la crasse, et les Occidentaux des ONG voyaient là une sorte de dépression collective - de pannévrose." 
The diggers make their way to the "so generous and caring" NGO donors in exactly the same way that they dig their burrows in search of malachite. They are magnetized by money. Their bodies remain in the burrow even when the malachite is brought to the surface.

In A Thousands Plateaus, Gilles Deleuze and Félix Guattari write of a "Holey Space,"11 an alternative to the duality between "Striated Space" and "Smooth Space." They perceive this circulatory dimension of the mine, which leads the miners in itinerant adventures:

There are no nomadic or sedentary smiths. Smiths are ambulant, itinerant. Particularly important in this respect is the way in which smiths live: their space is neither the striated space of the sedentary nor the smooth space of the nomad. Smiths may have a tent, they may have a house; they inhabit them in the manner of an "ore bed" (gite, shelter, home, mineral deposit), like metal itself, in the manner of a cave or a hole, a hut half or all underground.

456

Diggers are not nomads; they do not cross borders. Instead, they connect territories through their holes. They make the earth a "gruyère." The house-shelters mentioned by Deleuze and Guattari (we could also speak of house-holes) recall to mind the episode in the third chapter of Sony Labou Tansi's Les Yeux du volcan ("The Eyes of the Volcano") (1988), in which the little Louise Argandov ends up in the huge septic tank "twelve meters deep, three long and two wide, dug at the back of Isidor-Langouaro Street" (43). The villas of the dominant classes, with their "crappy pit," are semi-subterranean huts, half-buried in the ground, not far from the troglodyte habitat.

In cities near mines, the solidity of the floor is more important than that of the roof. The habitat is connected to the underground galleries, an open hole beneath the basement. ${ }^{12}$ The Congolese literature of the mine reveals that the

11 "Holey Space [espace troué]: the 'third space' of the machinic phylum (of matter-flow), inhabited by itinerant metallurgists, and by extension the 'underground' space that can connect with smooth space and be conjugated by striated space. Holey space is the subsoil space of 'swiss cheese' that bypasses both the ground [sol] of nomadic smooth space and the land [terre] of sedentary striated space. In this bypassing, holey space is suspect; for Gilles Deleuze, the mark of Cain is not the biblical mark of the soild, but a mark of the subsoil [sous-sol], since holey space is conceived of by surface dwellers as created by theft and betrayal" (Bonta and Protevi 95).

12 Following a fact-finding trip, the French writer Maylis de Kerangal wrote a very eloquent book about the mining town of Kiruna in the north of Sweden, which is being moved 
colonial conquest, which never ceased to claim a territorial dimension, actually had its eyes set on the subsoil and was not interested in what was happening on the surface.

Corruption is a central motif of these "underground" novels. It undermines social institutions and widens its hidden galleries until it provokes local collapses, heralding a global disaster. Whether possessed by states or oligarchs, the mine nevertheless becomes the subject of corruption's clandestine activities:

Mines are a source of flow, mixture, and escape with few equivalents in history. Even when they are well controlled by an empire that owns them (as in the Chinese and Roman empires), there is a major movement of clandestine exploitation, and of miner's alliance either with nomad and barbarian incursions or peasant revolts.

DELEUZE and GUATTARI 455

Corruption enables the underground circulation of money, so it is not surprising that it is closely associated with the network of galleries that eat away at the city. In reference to Kinshasa's road, De Boeck and Baloji explain that the potholes are sources of income for those who support them: "They have to make sure, therefore, that the pothole never gets filled up. That is why the same men, at night, will empty the pothole they had been busy filling the previous day, in order to secure some earnings, however small, the next day" (110).

The idea that money is the great "digger" in the neoliberal regime cannot be better expressed. Yet it seems necessary to distinguish two modalities of diggers: those who operate within a situation of survival, or those who operate out of a logic of accumulation. The animal of "The Burrow", in Franz Kafka's famous short story, represents the conjunction of these two figures: he is both the predatory owner who accumulates his booty at the bottom of the burrow and the defenseless victim, devoured by his own work, doomed to death at the bottom of his hole. The obstinate energy that animates the animal of the burrow does not depend on being predator, or a victim; rather, this energy comes from contact with the subsoil. The digger is not simply a survivor trapped within an implacable mechanic; he is also animated by prospective energy. He digs to open possibilities, hence his stubbornness and determination.

house by house as the basements have been weakened by the mining galleries (Kerangal 2019). 
The digger is a being of desire, and the mine is a great place for libidinal investment. The extractivist frenzy that undermines the territories and puts the land at risk of collapse is related to sexual frenzy by many authors. In many novels of the mine, prostitution is everywhere. The prostitutes, whose explosive voices punctuate Fiston Mwanza Mujila's novel Tram 83, are the fireflies that assail the miners coming out of the gallery. They play a major role in the narrative economy of this novel, because they are "the spirit of the hole." Prostitutes are viewed as sex "zombies," and they get in the way of diggers who are invited to dig galleries in what Aanza calls their "biology." That is, their own body, a resource from which they seek to make the greatest profit. The "ducklings" (les canetons), or the minor prostitutes, in Mujila's novel are formidable predators who throw their bodies in the middle of the road, demanding to be purchased. In the immediate vicinity of the digger, they represent a possible channel for the flow of money.

The sexual frenzy that takes hold of mining towns determines their literary configuration:

Some cities do not need literature: they are literatures. They parade with their chests stuck out, beacons of reason and clear thinking. They are proud and self-assured despite the trash bags they carry. The CityCountry, one example among many others ... She vibrated with literature.

- I love you, sweetheart.

- I do not like foreplay. It kills pleasure.

- Do you have the time?

She wrote her own story with her gigolos, her ducklings, her diggers, her four-star brothels, her dissident rebels ready to sequestrate you, her prospectors, her semi-tourists $[\ldots] .^{13}$

MUJILA 96

13 'Il est des villes qui n' ont pas besoin de littérature: elles sont littératures. Elles défilent poitrine bombée, la tête sur les épaules. Elles sont fières et s' assument en dépit des sacspoubelles qu' elles promènent. La Ville-Pays, un exemple parmi tant d' autres ... Elle vibrait de littérature.

- Je t' aime, mon chou.

- Je n' aime pas les préliminaires. Ça tue le plaisir.

- Vous avez l'heure?

Elle s'écrivait avec ses gigolos, ses canetons, ses creuseurs, ses bordels quatre étoiles, ses rebelles dissidents prêts à vous séquestrer, ses prospecteurs, ses semi-touristes [...].” 
The bodies of prostitutes are like galleries. Mujila pinpoints the connection between the corruption of the bodies and mining: "He took out his notebook, scribbled how much the railways, the minerals and the poorly controlled desires lead to the putrefaction of the bodies created to the image of riches"14 (96). At the bottom of the mine, there is money that the prostitutes pick up. This link between the mine and sex is not just metaphorical. The street girls say that it is illusory to believe in the possibility of finding a home in a world dedicated to mining and to the work of galleries. Sinzo Aanza says of their bodies, their "biologies," that they are streets:

[...] everyone came to get rid of their loneliness, the moment of a fierce race that is a loop towards oneself, their biologies with their intoxicating, thrilling, and sunny curves were illusory, derisory routes, which saved them and projected them out of loneliness, the biologies of these girls were streets..$^{15}$

The biologies of prostitutes are "illusory routes" because they are not permanent solutions. They are not promises of the future or of life, but the effects of what Patrice Yengo calls "witch capitalism," which makes money the supreme fetish in a nocturnal economy espousing all the characteristics of sorcery (Yengo 17-18). The body of a prostitute is a gallery where the money torn from the mine is swallowed up. Prostitutes have no illusions; they present their bodies abruptly and call for direct bodily contacts.

The digger, armed with his shovel and pickaxe, makes such a body-to-body experiment at the bottom of his gallery, and this can be strangely exalting, as in the scene from Labou Tansi's Les Yeux du volcan ("The Eyes of the Volcano") that was previously mentioned:

The crowd dug in singing. What had been seen as misfortune changed into frenzied enthusiasm. Clouds of screams. Cheers. Fanfares of pickaxes. In the midst of that smell of fresh, greasy earth, the grinding of wheelbarrows. The clumps of earth thrown up into the air fell moaning on the other

14 "Il sortit son calepin, griffonna combien les chemins de fer, les minerais et les désirs mal contrôlés conduisent à la putréfaction des corps créés à l'image des richesses [...]."

15 “[...] tout le monde venait y flatter sa solitude, l' instant d' une course acharnée qui est une boucle vers soi-même, leurs biologies aux courbes enivrantes, palpitantes et ensoleillées étaient des voies illusoires, dérisoires, qui rédimaient et projetaient hors de la solitude, les biologies de ces filles étaient des rues." 
side of the Argandov concession, at the foot of the Saint-Firmin Cathedral, under the admiring eyes of Mgr. Isodore Langouaro's mausoleum. Pickaxes, hoes, and shovels struck against a granite tongue that spit out sparks of sparks. ${ }^{16}$

$49^{-50}$

The gallery progresses with growing enthusiasm. The crowd falls on mysterious granite blocks obstructing the entrance to a cave that contains the skulls of ancestors, victims of a massacre. History wakes up under the blows of pickaxes. The history of the lived experience of colonized peoples has not been eradicated; it has simply disappeared under the surface in a sedimentary layer. The diggers meet the underground monsters of history. In an apocalyptic configuration, holes, galleries, and caves provide access to open crimes. The history of colonized peoples, overlooked for so long, is an immense sedimentary layer; it is necessary to dig underground to recover it.

In Bofane's Congo Inc., the sexual encounter between Isookanga and the anthropologist Aude Martin, who searches the heart of the forest for authentic beings, will also dispel any illusion about relations between Africa and Europe. If a pygmy is, for Martin, the image charged with metaphysical depths of an agreement between the forest and men, Isookanga, converted to extractivism, believes only in the exploitable strata of the subterranean basement. The sex scene reduces any illusion of depth. Isookanga's uncircumcised penis (boa or python), in the "Calvin Klein slip" under the Superdry jeans, escapes control and burrows into the "bottomless well" of Martin's vagina, without being aware of the "extreme sensitivity of the young woman's mucous membranes" (195):

Braced on his thighs, he did not know that every stroke of hips was - for her - like the whip that his ancestors had suffered during slavery; that every assault between her open thighs was as pitiless as the sharp ax of the hands, as the whip of Leopold II and his descendants; that each penetration of his sex provoked turbulence worthy of a riot for independence; that every jolt in his sensitive belly resounded like the salvos fired

16 "La foule creusait en chantant. Ce qui avait été un malheur se changeait en enthousiasme effréné. Nuées de cris. De hourras. Fanfares de coups de pioche. Au milieu de cette odeur de terre fraîche, grasse, le grincement des brouettes. Les mottes de terre envoyées en l' air retombaient en gémissant de l'autre côté de la concession des Argandov, au pied de la cathédrale Saint-Firmin, sous les yeux admiratifs du mausolée de Mgr Isodore Langouaro. Pioches, houes et pelles frappèrent contre une langue de granit qui cracha des gerbes d'étincelles." 
by wild neocolonialism, like the dictates of the International Monetary Fund, like UN resolutions, like a reissue of Tintin in Congo, like a misinformed French president's Dakar speech, as the propaganda of racist remarks in the twittosphere. ${ }^{17}$

196

Everything plays out in a contact of surfaces. Aude Martin becomes, in this moment of terrible sexual violence, a "girl-street" (fille-rue). The history of Africa reveals itself in her as a superposition of sedimented layers, which the digger awakens with each stroke of his hips. In the turbulence of the Aude Martin's body, the West, which needs to give an abstract depth (profondeur) to others to continue to delude itself on its own deeps (profonds), makes the painful experience of a concrete friction with the entire world.

\section{5}

\section{Conclusion}

The writings of the Congolese mine are a form of world literature that proceeds underground. The diggers sink into the earth to cross it and not to anchor themselves there by remaining faithful to a land. It is not a question of digging tombs to bury oneself, but of digging galleries that allow communication among them and that introduce resonance of a world turned sluggish. About an underwater city discovered by the protagonists of "The Legend of Londema," Paul LomamiTchibamba stumbles upon a formula that could serve as a prospectus for mine literature, "a dream materialized in the reality of palpable things"18 (204). As haggard or dazed as they are, the diggers of Fiston Mwanza Mujila and Sinzo Aanza's novels open gaps in the world; they are carriers of new horizons.

17 “Arc-bouté sur les cuisses, il ignorait que chaque coup de rein qu'il lui portait était - pour elle - comme le fouet que ses ancêtres avaient subi lors de l' esclavage; que chaque assaut entre ses cuisses ouvertes était aussi impitoyable que la hache tranchant des mains, que la chicotte infligée par Léopold II et ses descendants; que chaque pénétration de son membre provoquait une turbulence digne d'une émeute pour l'indépendance; que chaque secousse dans son ventre sensible résonnait comme les salves tirées par le néocolonialisme sauvage, comme les diktats du Fonds monétaire international, comme les résolutions de l'onu, comme une réédition de Tintin au Congo, comme le discours de Dakar d'un président français mal informé, comme la propagande de propos racistes dans la twittosphère."

18 "un rêve matérialisé dans la réalité des choses palpables." 


\section{Works Cited}

Aanza, Sinzo. Généalogie d'une banalité. La Roque d'Anthéron: Vents d' ailleurs, 2015.

Bednik, Anna. Extractivisme. Exploitation industrielle de la nature. Paris: Le passager clandestin, 2016.

Beecroft, Alexander. An Ecology of World Literature. From Antiquity to the Present Day. London: Verso, 2015 .

Bennett, Michael, and David W. Teague. The Nature of Cities: Ecocriticism and Urban Environments. Tucson: University of Arizona Press, 1999.

Bofane, In Koli Jean. Congo Inc.: Le testament de Bismarck. Arles: Actes Sud, 2014.

Bofane, In Koli Jean. Congo Inc.: Bismarck's Testament. Translated by Marjolijn de Jager. Bloomington: Indiana UP, 2018.

Bonta, Mark, and John Protevi. Deleuze and Geophilosophy: A Guide and Glossary. Edinburgh: Edinburgh UP, 2004.

Caminero-Santangelo, Byron. Different Shades of Green:African Literature, Environmental Justice, and Political Ecology. Charlottesville: University of Virginia Press, 2014.

De Boeck, Filip, and Sammy Baloji. Suturing the City: Living Together in Congo's Urban Worlds. London: Autograph ABP, 2016.

Deleuze, Gilles, and Félix Guattari. A Thousand Plateaus: Capitalism and Schizophrenia [1980]. Trans. Brian Massumi. London: Continuum, 2004.

Glissant, Édouard, and François Noudelmann. L'Entretien du monde. Saint Denis: Presses Universitaires de Vincennes, 2018.

Ghosh, Amitav. "Petrofiction: The Oil Encounter and the Novel." The New Republic (1992), 29-34.

Gómez-Barris, Macarena. The Extractive Zone: Social Ecologies and Decolonial Perspectives. Durham: Duke up, 2017.

Heise, Ursula K. Sense of Place and Sense of Planet: The Environmental Imagination of the Global. New York: Oxford UP, 2008.

Iheka, Cajetan. Naturalizing Africa: Ecological Violence, Agency, and Postcolonial Resistance in African Literature. Cambridge: Cambridge UP, 2017.

Kerangal, Maylis, Kiruna. Paris: La Contre allée, 2019.

Labou Tansi, Sony. Les Yeux du volcan. Paris: Seuil, 1988.

Latour, Bruno. Down to Earth: Politics in the New Climatic Regime. Trans. Catherine Porter. Medford: Polity Press, 2018.

Lomami-Tchibamba, Paul. Ngando. Kinshasa: Éditions Lokole/Présence Africaine, 1982.

Martinez-Alier, Joan. The Environmentalism of the Poor: A Study of Ecological Conflicts and Valuation. Cheltenham: Edward Elgar, 2002.

Mitchell Timothy. Carbon Democracy. Le pouvoir politique à l'ère du pétrole. Paris: Editions de la découverte, 2013 .

Morris, Rosalind C. “The Miner's Ear." Transition 98 (2008), 96-115. 
Mujila, Fiston Mwanza. Tram 83. Paris: Éditions Métailié, 2014.

Nixon, Rob. Slow Violence and the Environmentalism of the Poor. Cambridge: Harvard UP, 2011.

Ondjaki. Os Transparentes. Alfragide: Editorial Caminho, 2012.

Pepetela. O Desejo de Kianda. Lisboa: Publicações Dom Quixote, 1995.

Yengo, Patrice. Le Ventre. Les mutations sorcières dans le Bassin du Congo. Paris: Karthala, 2015.

White, Tim, and Sarah Sharkey. "Critical Zone Oxford Bibliography." In Oxford Bibliographies Online, 2016. Dor: 10.1093/OBO/9780199363445-0055. 